\title{
Potassium-induced resistance of cotton against boll-rottening, thrips and mealybugs
}

Zia-ul-hassan ${ }^{1 *}$, Aneel Kumar ${ }^{1}$, Khalid Hussain Talpur ${ }^{1}$, Fahad Nazir Khoso $^{2}$, Niaz Ahmed Wahocho ${ }^{3}$, Javaria Afzal ${ }^{1}$, Naheed Akhter Talpur ${ }^{1}$ and Saima Kalsoom Babar ${ }^{1}$

1. Department of Soil Science, Sindh Agriculture University, Tandojam-Pakistan

2. Department of Entomology, Sindh Agriculture University, Tandojam-Pakistan

3. Department of Horticulture, Sindh Agriculture University, Tandojam-Pakistan

*Corresponding author's email: zhnshah@gmail.com

Citation

Zia-ul-hassan, Aneel Kumar, Khalid Hussain Talpur, Fahad Nazir Khoso, Niaz Ahmed Wahocho, Javaria Afzal, Naheed Akhter Talpur, Saima Kalsoom Babar. Potassium-induced resistance of cotton against boll-rottening, thrips and mealybugs. Pure and Applied Biology. Vol. 10, Issue 1, pp234-243.

http://dx.doi.org/10.19045/bspab.2021.100024

Received: $13 / 06 / 2020 \quad$ Revised: $24 / 08 / 2020$

Accepted: 04/09/2020

Online First: 16/09/2020

\section{Abstract}

Understanding the role of potassium $(\mathrm{K})$ to increase crop stress tolerance is very important, and hence, explored in cotton (Gossypium hirsutum L.). The field experiment was conducted on a non-saline, alkaline, poorly fertile, K-deficient, sandy clay loam soil, following randomized complete block split-plot design, repeated thrice. Eight cotton genotypes, Sindh-1, Hari Dost, NIAB-78, CRIS-134, CRIS-142, CRIS-121, Sadori and Chandi-95 received two $\mathrm{K}$ doses, i.e. 0 (deficient-K) and 72 (adequate-K) $\mathrm{kg} \mathrm{K}_{2} \mathrm{O}$ $\mathrm{ha}^{-1}$. Adequate-K increased sympodia (40\%), bolls (36\%), stem-diameter (23\%), seed-cotton yield (37\%) and $\mathrm{K}$ concentration (109\%), while decreased boll-rottening (61\%), thrips (77\%) and mealybugs (88\%). Maximum increase in sympodia was observed for NIAB-78 (79\%) while minimum for Chandi-95 (13\%). Maximum increase in bolls was recorded for NIAB-78 (67\%) while minimum for Chandi-95 (17\%). Maximum increase in stem-diameter was noted for NIAB-78 (69\%) while minimum for Chandi-95 (4\%). Maximum increase yield of seed cotton was observed for NIAB-78 (73\%), while minimum for Chandi-95 (15\%). K concentration was found highest for NIAB-78 (164\%) while minimum for Chandi-95 (52\%). Maximum decrease in boll-rottening was observed in case of CRIS-142 (79\%) while minimum decrease was noted in case of Chandi-95 (17\%). Maximum decrease in thrips was observed for Chandi-95 (81\%), while minimum decrease for Hari-Dost (72\%). Mealybugs were $100 \%$ less at adequate-K, while CRIS121 was completely safe. In crux, adequate-K increased growth and yield of cotton genotypes by enhancing their stress tolerance. NIAB-78 was the most K-deficiency cotton genotype while Chandi-95 was the most tolerant, with highest and lowest response to K-nutrition, respectively.

Keywords: Boll-rottening; Cotton; Cotton yield; CRIS-121, Mealybug; NIAB-78, Potassium; Thrips Introduction

Pests and diseases play havoc with the sustainability of crop production. Farmers spend billions of dollars annually to protect plants from insect pests and diseases [1].

Nonetheless, pests and diseases globally cause $20-40 \%$ reduction in crop yield [2]. In Pakistan, the total consumption and the amount spent on pesticides increased from 94265 M.T. and 10534 Million Rs., 
respectively, during 2007 to 206730 M.T. and 43535 Million Rs., respectively, during 2017, i.e. $119 \%$ and $313 \%$ more, respectively, in a decade [3]. Interestingly, most of this pesticide is used for cotton crop in order to achieve economically optimum yield.

Cotton is an important fiber crop of Pakistan. During 2016-17, cotton is grown on an area of 2489 thousand ha which offered a total production of 10671 thousand bales with $581 \mathrm{~kg} \mathrm{ha}^{-1}$ average yield. This was much lower $(-15 \%)$ when compared with the average yield of cotton during last 20 years $\left(687 \mathrm{~kg} \mathrm{ha}^{-1}\right)$ and much lower ($25 \%)$ when compared with the average cotton yield of last 5 years $\left(777 \mathrm{~kg} \mathrm{ha}^{-1}\right)$ [3]. One of the many important reasons for this yield decrease may be the disease and insect-pest infestation that cotton crop faces more than any other crop.

Plant nutrition greatly governs the susceptibility or resistance of plants to pests and diseases in sustainable agriculture [4]. Adequate $\mathrm{K}$ nutrition is reported to play important role in cotton [5] and enhances crop resistance against pests and diseases $[6$, 7]. Decreased incidence of $70 \%$ fungal diseases, 69\% bacteria diseases, $63 \%$ insects and mites, and $41 \%$ viruses was also reported as a result of adequate $\mathrm{K}$ nutrition, due to its effect on plant growth pattern, anatomy, morphology and chemistry [8]. It was also found that rice stem rot disease increased with increasing nitrogen supply on K-deficient rice soil [9]. Adequate K nutrition lowered the stem rot incidence and increased rice yield. Moreover, recommended $\mathrm{K}$ supply was also reported to lower the incidence of rice diseases, viz. brown leaf spot, blast or sheath blight and bacterial leaf blight with varying degree of resistance due to genotypic variation as more susceptible varieties had low or no resistance. Similar conclusion was drawn for plant resistance against insect-pests, e.g. for rice white backed plant hopper.

The indirect association between sesame and soybean $\mathrm{K}$ accumulation and disease incidence while direct relationship with yield was also reported earlier [10]. Moreover, it was also highlighted that adequate $\mathrm{K}$ nutrition can enhance plant resistance to diseases, due to the regulation of plant physiological metabolism pathways [11].

Adequate K nutrition was also found to play positive roles in lowering disease incidence and insect-pest infestation thereby increasing cotton yield, e.g. leaf applied $\mathrm{KNO}_{3}$ was useful to reduce Alternaria leaf blight effects in cotton [12]. Positive effects of $\mathrm{K}$ nutrition in enhancing the resistance of cotton against leaf curl virus of cotton are also advocated [13]. It is also reported that 12 to $38 \%$ reduction in cotton leaf curl virus was due to adequate $\mathrm{K}$ nutrition, though the magnitude of benefit was cultivar specific [7]. Similarly, it was also reported that adequate $\mathrm{K}$ nutrition increased cotton tolerance against diseases and insect-pests [14]. The above highlighted positive effects of $\mathrm{K}$ might be due to the fact that $\mathrm{K}$ deficiency restricts reproductive success by way of changing carbohydrate- protein balances in cotton [15]. Recent studies found adequate $\mathrm{K}$ nutrition elevating seedcotton yield of early maturing $\mathrm{Bt}$ cotton [16]. We aimed at evaluating K-induced pest and disease resistance in cotton and its consequences on growth, $\mathrm{K}$ accumulation and yield of selected genotypes of cotton.

\section{Materials and Methods \\ Properties of experimental soil}

The soil used in this study, as analyzed following standard methods [17], was sandy clay loam in texture, alkaline by nature (8.1 $\mathrm{pH})$ and non-saline $\left(1.21 \mathrm{dS} \mathrm{m}^{-1}\right.$ electrical conductivity). Moreover, the soil was poor in organic matter $(0.68 \%)$ while ammonium bicarbonate-diethylene triamine penta acetic 
acid (ABDTPA) extractable soil-K was low (123 $\left.\mathrm{mg} \mathrm{kg}^{-1}\right)$.

\section{Experimental design and treatment details}

The study followed randomized complete block design with split-plot arrangement having three repeats. Cotton genotypes (Sindh-1, Hari Dost, NIAB-78, CRIS-134, CRIS-142, CRIS-121, Sadori and Chandi95) were grown in main plots while $\mathrm{K}_{2} \mathrm{O}$ rates $\left(0 \mathrm{~kg} \mathrm{ha}{ }^{-1}\right.$, i.e. no $\mathrm{K}$ fertilizer application which served as control treatment and $72 \mathrm{~kg} \mathrm{~K}_{2} \mathrm{O} \mathrm{ha}^{-1}$ which served as adequate level) were assigned to sub plots. The sub-plot size was $7.5 \mathrm{~m} \times 5 \mathrm{~m}=$ $37.5 \mathrm{~m}^{2}$.

\section{Sowing of crop}

Cotton genotypes were sown at 1.0 and 2.5 $\mathrm{ft}$ distance between plants and rows, respectively. The standard agronomic, cultural and production practices were adopted throughout study.

\section{Fertilizer application}

For K nutrition, potassium sulphate fertilizer (SOP) $\left(50 \% \quad \mathrm{~K}_{2} \mathrm{O}\right)$ was applied at sowing. Recommended doses of nitrogen $(\mathrm{N})(160$ $\mathrm{kg} \mathrm{ha}{ }^{-1}$ ) and phosphorus (P) (80 kg ha-1) were also applied as urea $(46 \% \mathrm{~N})$ and diammonium phosphate (DAP) $(18 \% \mathrm{~N}$ and $46 \% \mathrm{P}_{2} \mathrm{O}_{5}$ ), respectively. Full dose of $\mathrm{P}$ plus $50 \% \mathrm{~N}$ was broadcasted and mixed well to soil. Leftover $\mathrm{N}$ was applied at first irrigation.

\section{Growth and yield observations}

Five plants were sampled from each sub-plot for observing various growth and yield traits, coupled with the number of plants infected by thrips, mealybug and bollrottening.

Plant sampling, processing and analysis

Leaf-K concentration was analyzed as reported earlier [18].

\section{Statistical analysis}

Statistical analysis, i.e. analysis of variance (ANOVA) was done by statistical software Statistix ver. 8.1. Means were separated through using Tukey's Honestly Significant Difference (HSD) test at alpha 0.05.

Results

Number of sympodia (plant ${ }^{-1}$ )

Adequate supply of $\mathrm{K}$ significantly produced $40 \%$ more sympodia as against deficient K (Fig. 1). Cotton genotypes exhibited wide genotypic variation to produce sympodia in response to balanced $\mathrm{K}$ fertilization against its deficient level. Maximum increase in sympodia was observed in case of NIAB-78 (79\%) followed by Sindh-1 (53\%), while minimum increase was noted in case of Chandi-95 $(13 \%)$ followed by Sadori $(20 \%)$.

Number of bolls (plant ${ }^{-1}$ )

Adequate $\mathrm{K}$ nutrition produced $36 \%$ more bolls as compared to deficient K (Fig. 2). Cotton genotypes exhibited wide genotypic variation to produce number of bolls in response to adequate $\mathrm{K}$ supply against its deficient level. Maximum increase in number of bolls was observed in case of NIAB-78 (67\%) followed by Sindh-1 (54\%), while minimum increase was noted in case of Chandi-95 (17\%) followed by Sadori $(14 \%)$.

\section{Stem diameter ( $\left.\mathrm{mm}_{\text {plant }} \mathbf{1}^{-1}\right)$}

Adequate $\mathrm{K}$ fertilization significantly increased stem diameter (23\%) against deficient $\mathrm{K}$ (Fig. 3). Cotton genotypes exhibited wide genotypic variation to produce stem diameter in response to adequate K supply against its deficient level. Maximum increase in stem diameter was observed in case of NIAB-78 (69\%) followed by Hari-Dost (24\%), while minimum increase was noted in case of Chandi-95 (4\%) followed by Sadori (14\%).

Seed cotton yield ( g plant $^{-1}$ )

Adequate $\mathrm{K}$ supply increased seed cotton yield by $37 \%$ when compared to deficient $\mathrm{K}$ (Fig. 4). All the cotton genotypes exhibited wide genotypic variation to produce cotton yield in response to adequate $\mathrm{K}$ fertilization against its deficient level. Maximum 
increase in cotton yield was noted in case of NIAB-78 $(73 \%)$ followed by Sindh-1 $(53 \%)$, while minimum increase was noted in case of Chandi-95 (15\%) followed by Sadori $(17 \%)$

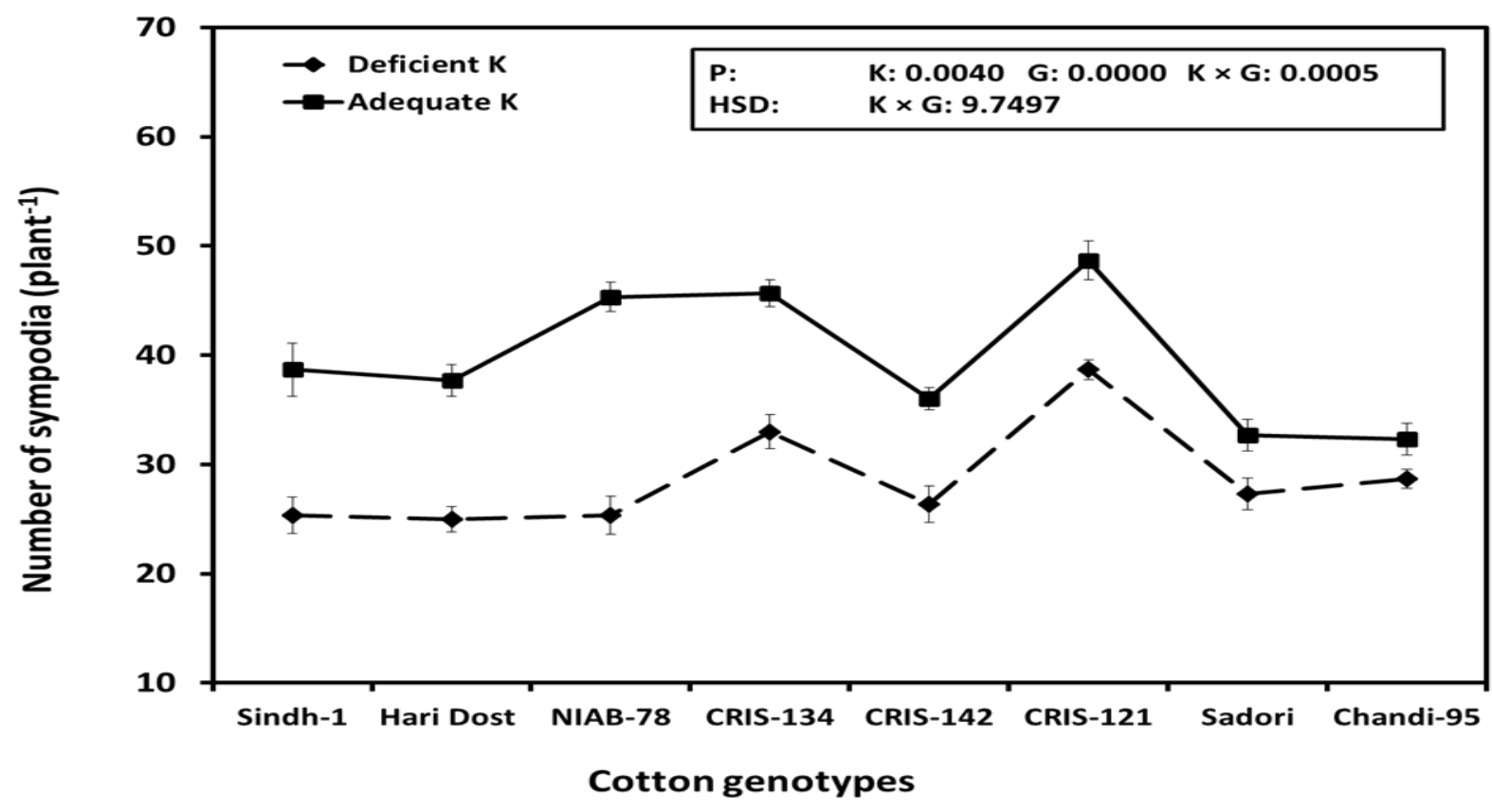

Figure 1. Number of sympodia (plant ${ }^{-1}$ ) of cotton genotypes at deficient and adequate levels of potassium. Values are means of three replications. Vertical bars represent \pm standard error of means. The abbreviations ' $P$ ' and 'HSD' denote 'P-value' and 'Tukey's Honestly Significant Difference' at alpha 0.05 , respectively

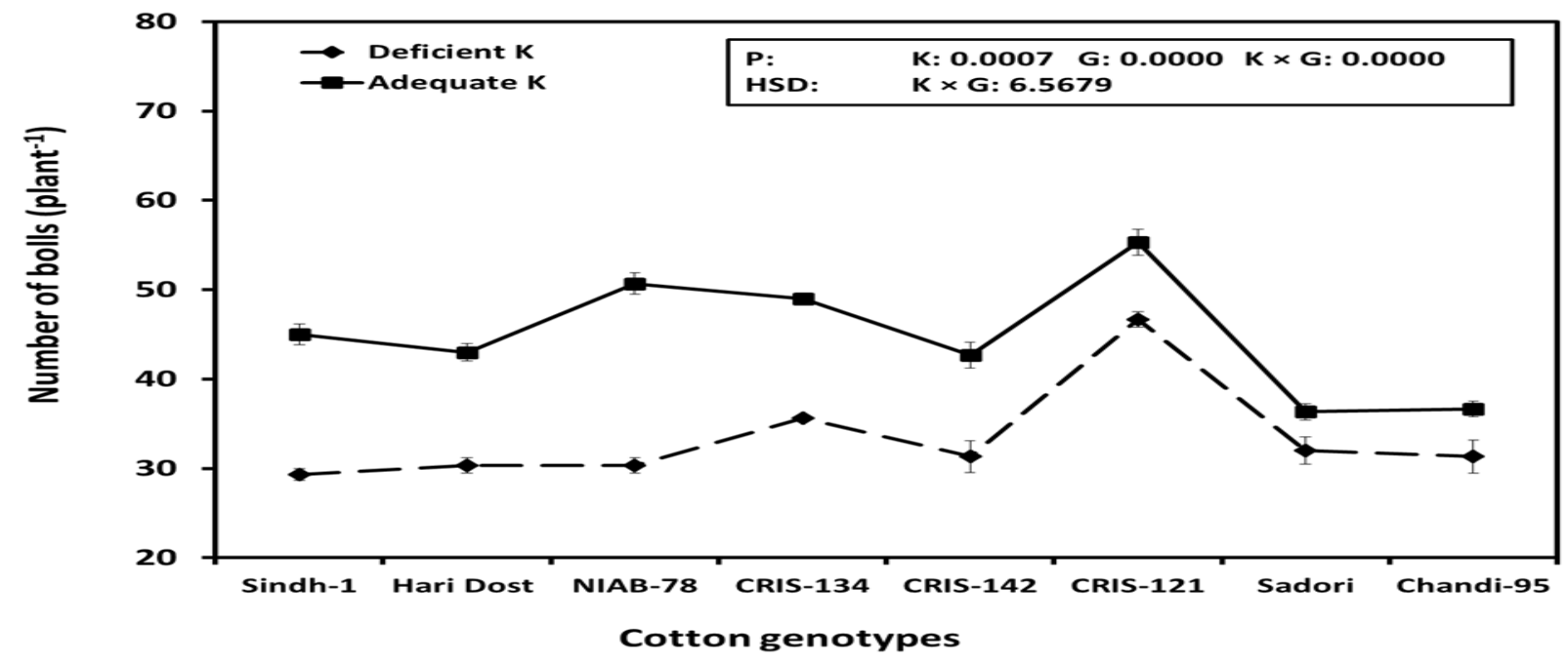

Figure 2. Number of bolls (plant ${ }^{-1}$ ) of cotton genotypes at deficient and adequate levels of potassium. Values are means of three replications. Vertical bars represent \pm standard error of means. The abbreviations ' $P$ ' and 'HSD' denote 'P-value' and 'Tukey's Honestly Significant Difference' at alpha 0.05 , respectively 


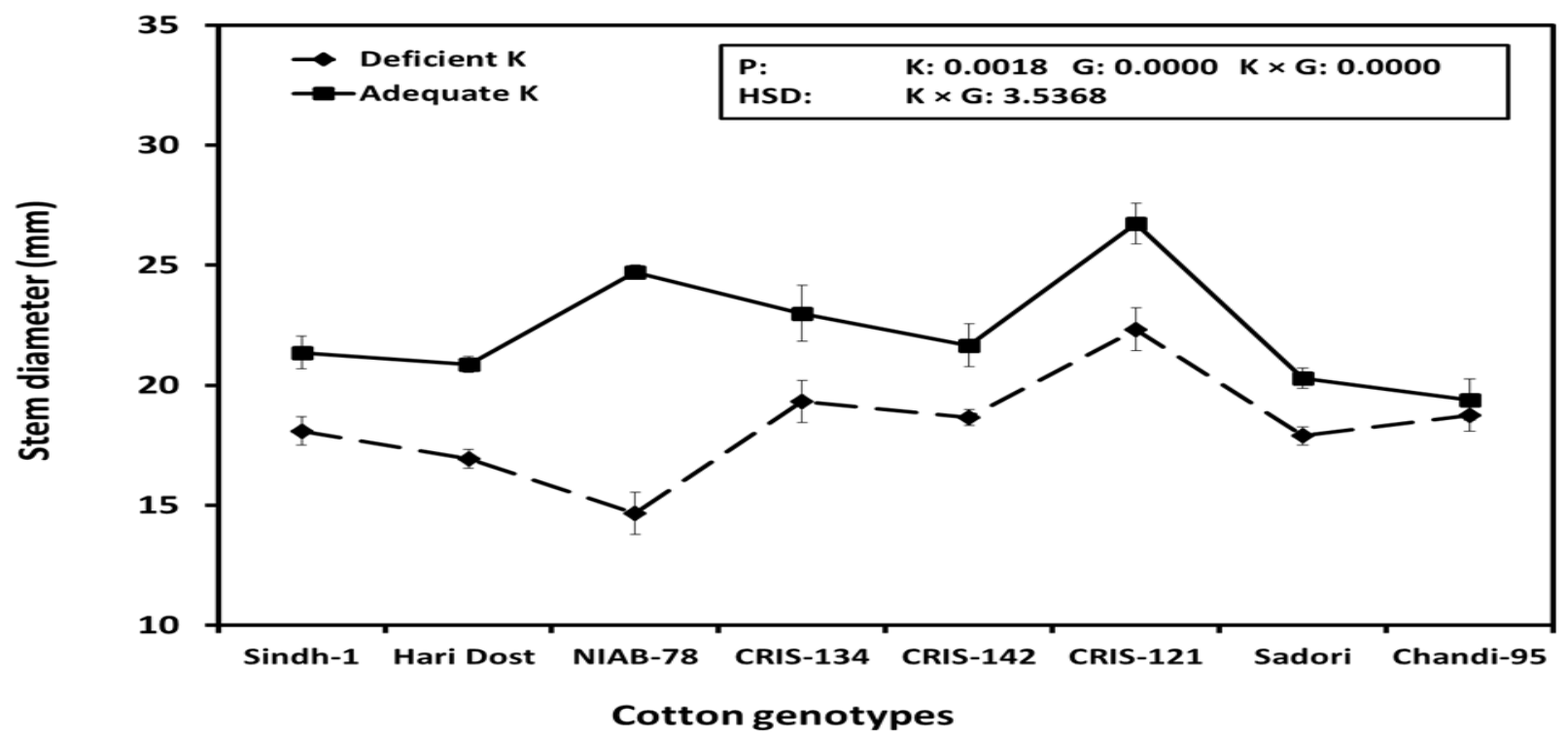

Figure 3. Stem diameter $(\mathrm{mm})$ of cotton genotypes at deficient and adequate levels of potassium. Values are means of three replications. Vertical bars represent \pm standard error of means. The abbreviations ' $P$ ' and 'HSD' denote 'P-value' and 'Tukey's Honestly Significant Difference' at alpha 0.05 , respectively

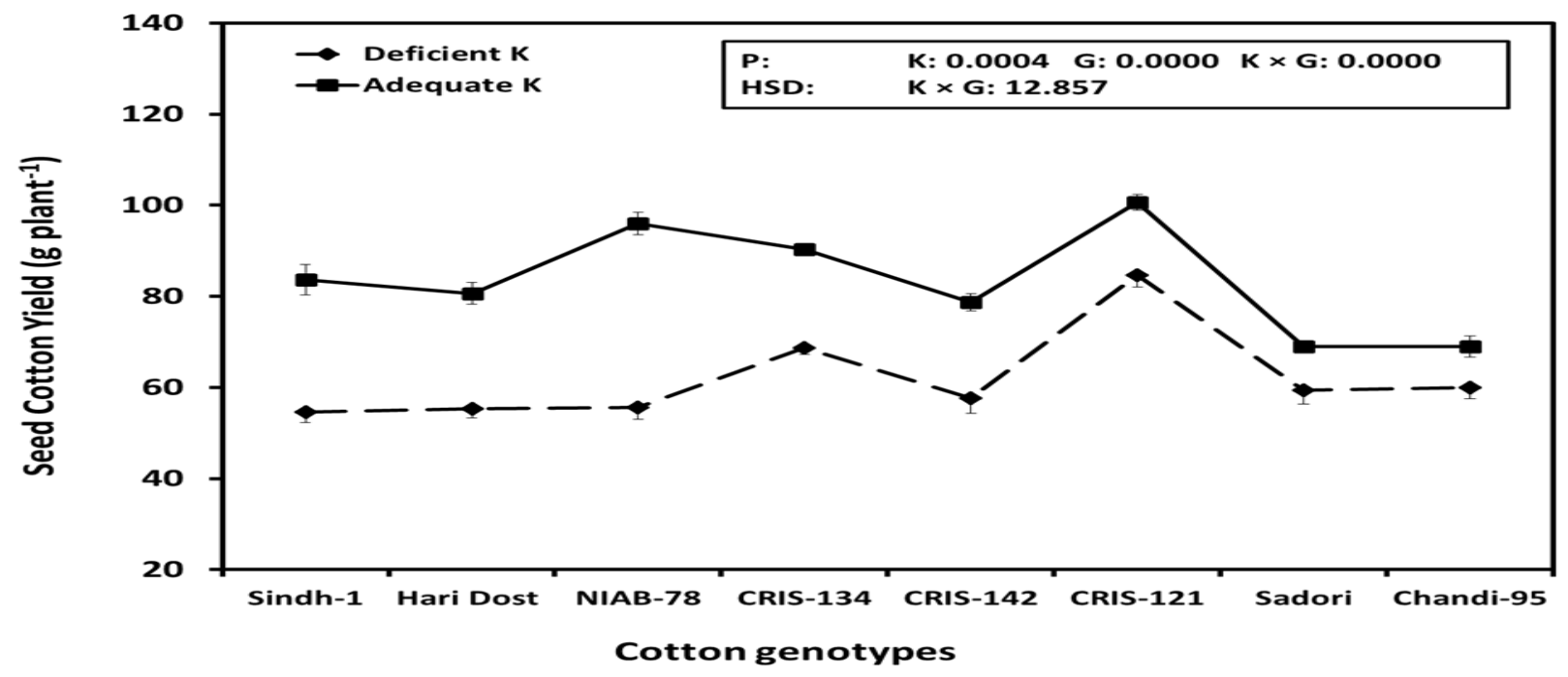

Figure 4. Seed cotton yield ( g plant $^{-1}$ ) of cotton genotypes at deficient and adequate levels of potassium. Values are means of three replications. Vertical bars represent \pm standard error of means. The abbreviations ' $P$ ' and 'HSD' denote 'P-value' and 'Tukey's Honestly Significant Difference' at alpha 0.05 , respectively

K concentration $(\%)$

Adequate $\mathrm{K}$ fertilization improved accumulation of $\mathrm{K}$ in cotton $109 \%$ more as against deficient $\mathrm{K}$ (Fig. 5). Cotton genotypes exhibited wide genotypic variation in $\mathrm{K}$ accumulation in response to adequate $\mathrm{K}$ nutrition against its deficient level. Maximum increase in $\mathrm{K}$ accumulation was observed in case of NIAB-78 (164\%) followed by Sindh-1 (147\%), while 
minimum increase was noted in case of Chandi-95 (52\%) followed by CRIS-121 (54\%).

\section{Number of rottened bolls (plant ${ }^{-1}$ )}

Adequate $\mathrm{K}$ supply increased the resistance of cotton genotypes against boll-rottening disease which was $61 \%$ less when compared to its incidence at deficient $\mathrm{K}$ (Fig. 6). However, wide variation existed for this trait among cotton genotypes for this trait. Maximum decrease in boll-rottening was observed in case of CRIS-142 (79\%) followed by NIAB-78 (72\%), while minimum decrease was noted in case of Chandi-95 (17\%) followed by CRIS-121 $(57 \%)$, as a result of $\mathrm{K}$ nutrition.

\section{Number of thrips (plant ${ }^{-1}$ )}

Cotton genotypes responded significantly when $\mathrm{K}$ was supplied in adequate amount and their tolerance against thrips attack was increased to $77 \%$ as against its deficient $\mathrm{K}$ level (Fig. 7). In addition to this differential response of cotton genotypes at two K extremes, all the cotton genotypes exhibited wide genotypic variation in their resistance against thrips attack in response to adequate $\mathrm{K}$ fertilization against its deficient level. Maximum decrease in thrips infestation was observed in case of Chandi-95 (81\%) followed by CRIS-121 (79\%), while minimum decrease was noted in case of Hari-Dost $(72 \%)$ followed by CRIS-142 (74\%).

\section{Number of mealy-bugs (plant ${ }^{-1}$ )}

Balanced $\mathrm{K}$ fertilization decreased mealybug infestation to $88 \%$ when compared to deficient K (Fig. 8). However, their existed negligible variation among cotton genotypes in their resistance against mealybugs attack in response to adequate $\mathrm{K}$ supply against its deficient level due to the fact that during the year of this study this agro-climatic region was safe from the attack of mealybugs and little mealybugs infestation was found at deficient $\mathrm{K}$ level. Nonetheless, mealybugs infestation was $100 \%$ lower when cotton genotypes received required amount of fertilizer $\mathrm{K}$ Interestingly, the cotton genotype CRIS121 was the only genotype for which no mealybugs infestation was noted. The mealybugs infestation in Sindh, as a matter of fact, is an infestation which is recorded during 2-3 years interval in cotton. Hence, no significant difference was found among cotton genotypes for this trait.

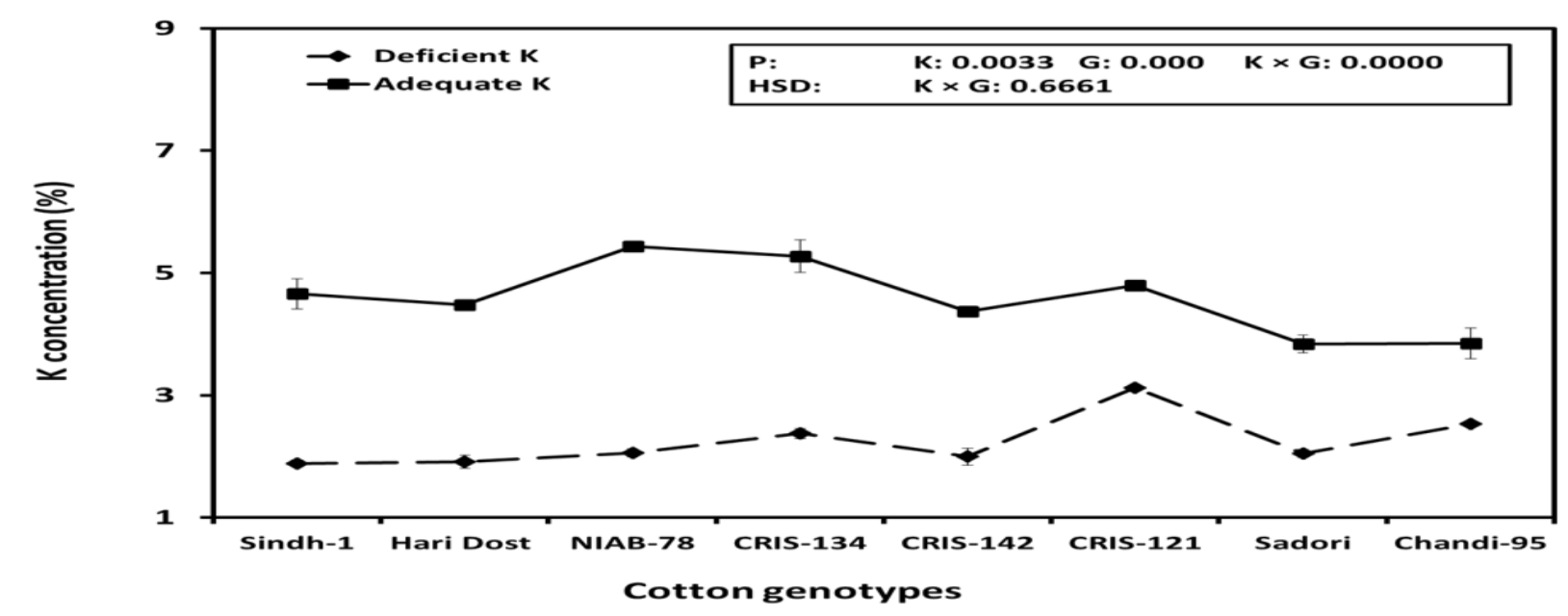

Figure 5. $\mathrm{K}$ concentration (\%) of cotton genotypes at deficient and adequate levels of potassium. Values are means of three replications. Vertical bars represent \pm standard error of means. The abbreviations ' $P$ ' and 'HSD' denote 'P-value' and 'Tukey's Honestly Significant Difference' at alpha 0.05 , respectively 


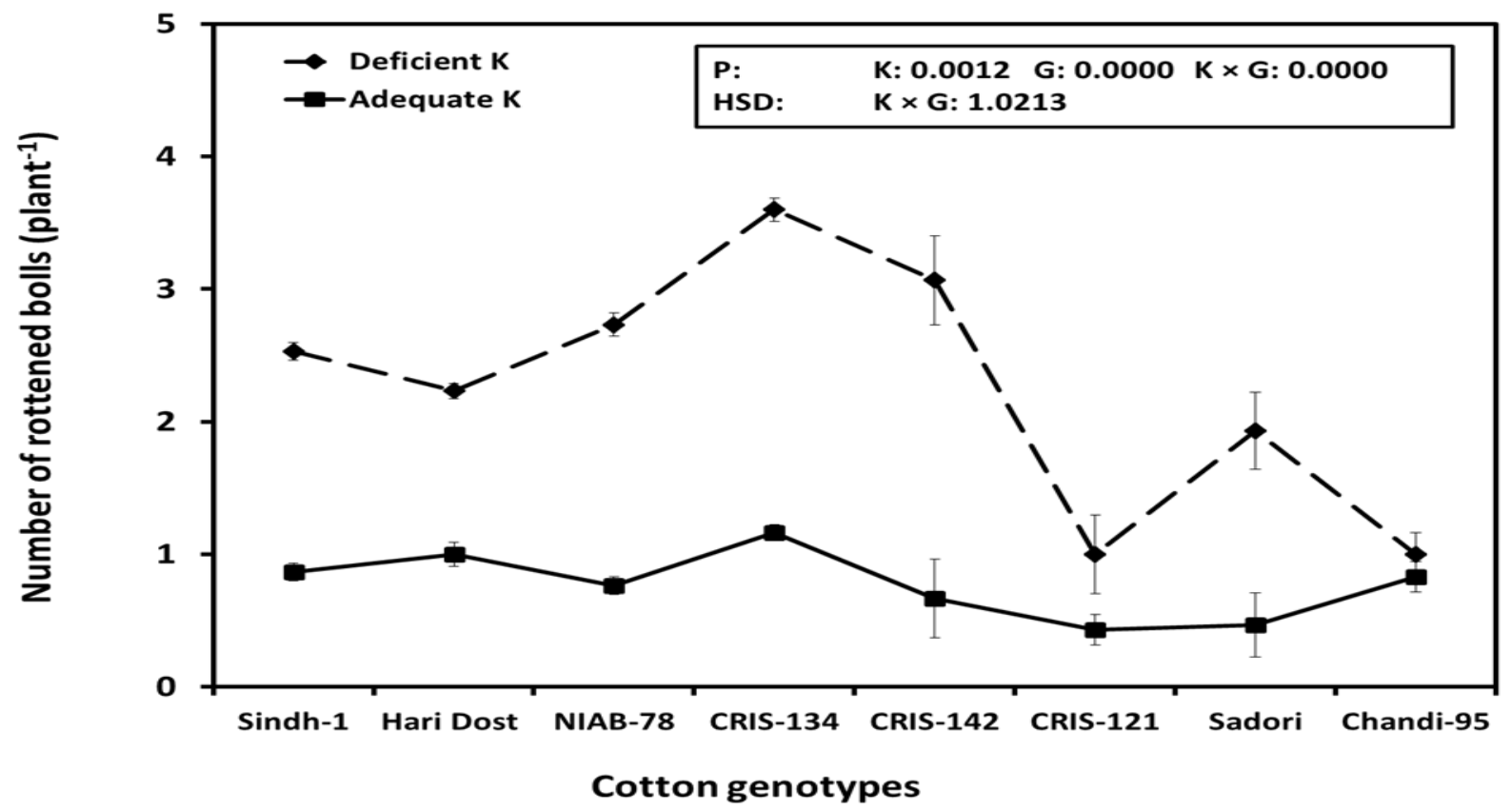

Figure 6. Number of rottened bolls (plant ${ }^{-1}$ ) of cotton genotypes at deficient and adequate levels of potassium. Values are means of three replications. Vertical bars represent \pm standard error of means. The abbreviations ' $P$ ' and 'HSD' denote 'P-value' and 'Tukey's Honestly Significant Difference' at alpha 0.05, respectively

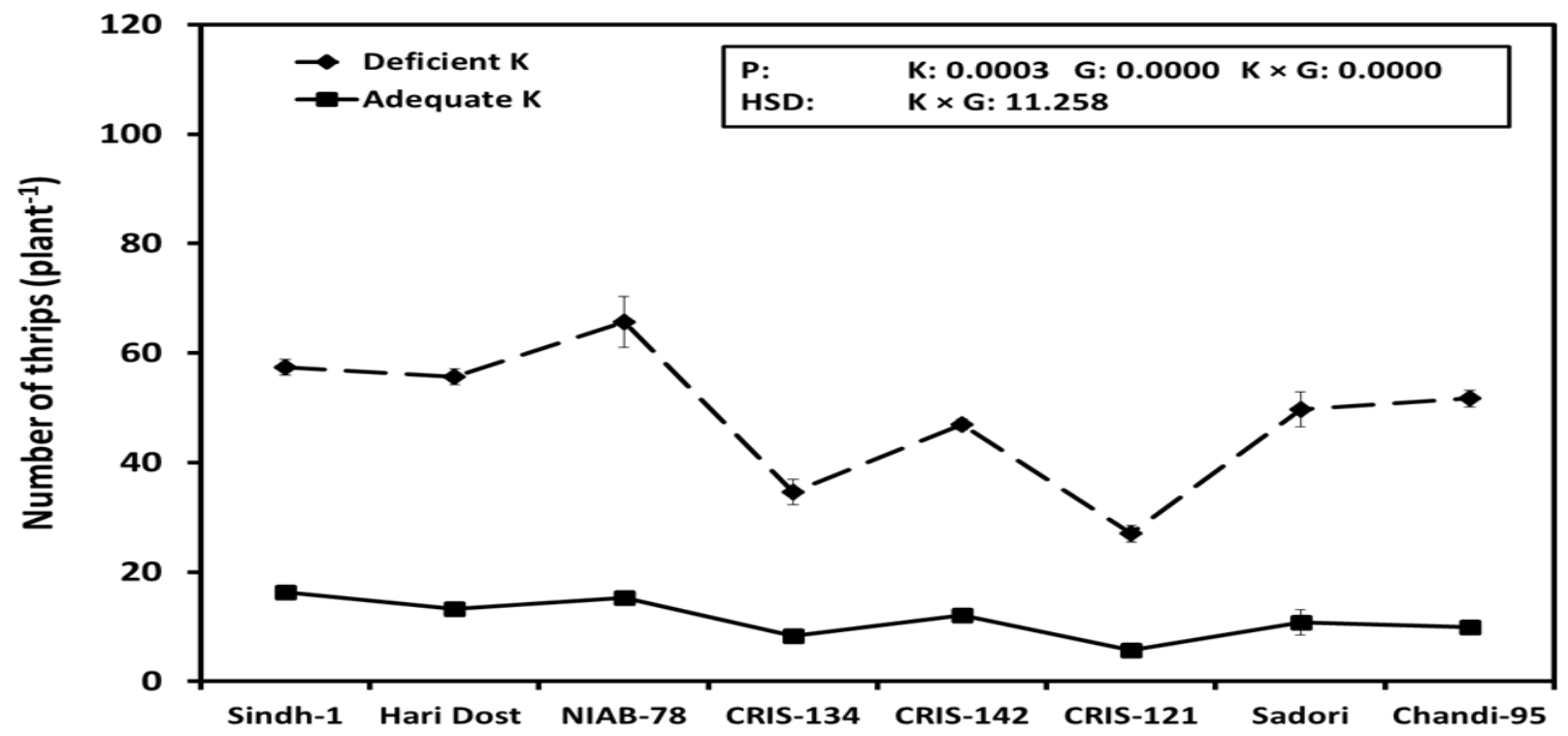

Figure 7. Number of thrips Cotton genotypes (plant ${ }^{-1}$ ) of cotton genotypes at deficient and adequate levels of potassium. Values are means of three replications. Vertical bars represent \pm standard error of means. The abbreviations ' $P$ ' and 'HSD' denote ' $P$ value' and 'Tukey's Honestly Significant Difference' at alpha 0.05, respectively 


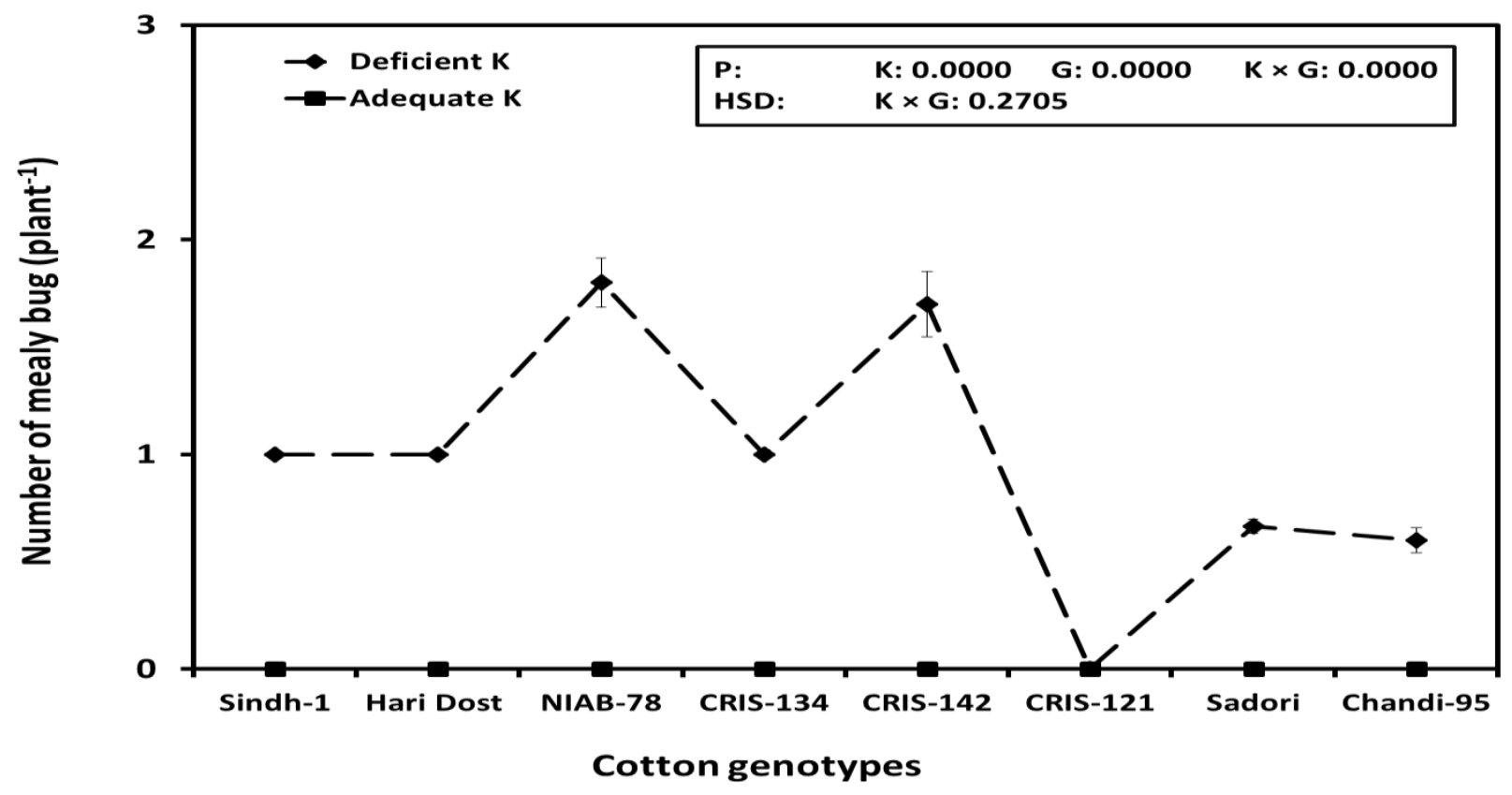

Figure 8. Number of mealybugs (plant ${ }^{-1}$ ) of cotton genotypes at deficient level of potassium. Values are means of three replications. Vertical bars represent \pm standard error of means. The abbreviations ' $P$ ' and 'HSD' denote 'P-value' and 'Tukey's Honestly Significant Difference' at alpha 0.05 , respectively

\section{Discussion}

The present field study highlighted wide differences among various genotypes of cotton for their $\mathrm{K}$ accumulation and disease and insect-pest tolerance. Moreover, the benefits of adequate $\mathrm{K}$ nutrition highlighted the significance of adequate $\mathrm{K}$ supply for cotton $[5$, , 16] (Hu et al., 2018; Shahzad et al., 2019; Chen et al., 2020). $\mathrm{K}$ positively contributes towards cotton growth and yield as one of the most important plant nutrients $[19,20]$. Cotton requires more $K$ as against its counterpart row crops [21] because its thin and ineffective root system, potentially able to explore from a distance of $0.10 \mathrm{~m}$ only [22]. Moreover, K deficiency affects stems, roots and bolls earlier than the leaves [23]. The consumption of $\mathrm{K}$ by cotton is believed to be equal to that of nitrogen [24] which requires its uninterrupted supply throughout the crop lifespan for improved growth and enhanced yield [25]. Kdeficiency restricts reproductive success by way of changing carbohydrate- protein balances in cotton [15] since K plays pivotal functions in plants from the stabilization of $\mathrm{pH}$ to osmo-regulation and in the transport processes of membranes to the activation of various enzymes [6]. $\mathrm{K}$ is also actively involved in the pressure potential of leaf and photosynthesis [26] besides developing the photosynthetic apparatus, the assimilation of $\mathrm{CO}_{2}$ [27] and water-use-efficiency [26]. Hence, adequate $\mathrm{K}$ nutrition of cotton is inevitable not only for biomass production $[18,24]$ but also for increasing the weight and size of bolls, yield of lint [28] and quality of fiber [29].

The present study further highlighted that adequate $\mathrm{K}$ decreased boll-rottening (16\%), thrips attack (77\%) and mealybug infestation (100\%). Early studies on this subject also endorse these findings advocating the positive role of balanced $\mathrm{K}$ fertilization in enhancing growth and yield of crops by triggering plant disease tolerance 
$[6-8,11,18,24,26]$. An early study reported the inverse relationship of $\mathrm{K}$ nutrition with disease incidence and pest infestation in rice and the positive effects of better $\mathrm{K}$ supply in enhancing disease resistance and yield of soybean and sesame [9]. Moreover, $\mathrm{K}$ is also reported to lower the intensity of leaf rust and enhance yield by increasing the weight of kernel [30]. Potassium accumulation in cotton leaf was found inversely associated with the infection of leaf curl virus of cotton [13]. The beneficial effects of leaf applied $\mathrm{KNO}_{3}$ in lowering the damage of Alternaria leaf blight in cotton were also documented [12]. The application of $250 \mathrm{~kg} \mathrm{~K} \mathrm{ha}^{-1}$ in cotton reduced leaf curl virus of cotton from 12 to $38 \%$, however, this effect was genotype specific [7]. Similarly, researchers also found that adequate $\mathrm{K}$ nutrition increased cotton tolerance against diseases and insect-pests [14].

\section{Conclusion}

Adequate $\mathrm{K}$ nutrition enhanced the tolerance of cotton genotypes against boll-rottening, thrips and mealybugs. NIAB-78 was most sensitive to deficient- $\mathrm{K}$ and responded more to adequate-K. Chandi-95 was most tolerant to deficient- $\mathrm{K}$ and did not respond to adequate-K. The enhancement of seed cotton yield was mainly because of lower thrips attack under adequate-K nutrition.

\section{Authors' contributions}

Conceived and designed the experiment: ZU Hassan, Performed the experiment: A Kumar, J Afzal \& KH Talpur, Analysed the data: ZU Hassan, J Afzal, NA Talpur \& SK Babar, Contributed materials/ analysis/ tools: ZU Hassan, KH Talpur, FN Khoso \& NA Wahocho, Wrote the paper: ZU Hassan, KH Talpur, FN Khoso \& NA Wahocho.

\section{References}

1. Yudelman M, Ratta A \& Nygaard D (1998). Pest management and food production. In: Food, agriculture and the environment. Discussion paper 25, International Food Policy Research Institute, Washington DC, USA.
2. FAO (UN Food Agric. Organ.). 2009. Global agriculture towards 2050. High Level Expert Forum, FAO, Rome, Italy.

3. GOP (Government of Pakistan). 2019. Agricultural Statistics of Pakistan 2016-17. $51^{\text {st }}$ Edition. Ministry of National Food Security and Research (Economic Wing), Government of Pakistan, Islamabad. pp. 272.

4. Dordas C (2008). Role of nutrients in controlling plant diseases in sustainable agriculture. A review. Agron Sustain Dev 28: 33-46.

5. Chen J, Zongduan G, Haining C, Xiuyi Y \& Jibiao G (2020). Effects of different potassium fertilizer types and dosages on cotton yield, soil available potassium and leaf photosynthesis. Arch Agron Soil Sci DOI: 10.1080/03650340.2020.1723005.

6. Marschner H (1995). Mineral Nutrition of Higher Plants. $2^{\text {nd }}$ ed. Academic Press, San Diego, CA, America. pp. $889+$ xv.

7. Pervez H, Ashraf M, Makhdum MI \& Mahmood T (2007). Potassium nutrition of cotton (Gossypium hirsutum L.) in relation to cotton leaf curl virus disease in aridisols. Pak J Bot 39(2): 529 - 539.

8. Perrenoud, S. 1990. Potassium and plant health. IPI Research Topics No. 3, $2^{\text {nd }}$ rev. edition. Basel/Switzerland.

9. Härdter R (1997). Crop nutrition and plant health of rice based cropping systems in Asia. Agrochem. News Brief 20(4): 29-39.

10. Mondal SS, Pramanik CK \& Das J (2001). Effect of nitrogen and potassium on oil yield, nutrient uptake and soil fertility in soybean (Glycine max) - sesame (Sesamum indicum) intercropping system. Indian $J$ Agric Sci 71: 44-46.

11. Liu X, Ping HE \& Ji-Yun J (2006). Advances in effect of potassium nutrition on plant disease resistance and its mechanism. Plant Nutr Fert Sci DOI: http://en.cnki.com.cn/Article_en/CJFDTOT AL-ZWYF200603025.htm.

12. Bhuiyan AB, Boyd MC, Dougall AJ, Martin C \& Hearnden M (2007). Effects of foliar application of potassium nitrate on suppression of Alternaria leaf blight of 
cotton (Gossypium hirsutum) in northern Australia. Aus J Plant Pathol 36: 462-465.

13. Iqbal N, Ashraf MY, Javed F, Ashraf M \& Hameed S (2006). Cotton leaf curl virus: ionic status of leaves and symptom development. J Integ Plant Biol 48(5): 558-562.

14. Zahi ES, Arif SA, Jehan BA, El-dewy EH, Naggar EL \& Madeha (2012). Inorganic fertilization of cotton field-plants in relation to sucking insects and yield production components of cotton. J Amer Sci 8(2): 509-517.

15. Hu W, Loka D, Fitzsimmons TR, Zhou Z \& Oosterhuis DM (2018). Potassium deficiency limits reproductive success by altering carbohydrate and protein balances in cotton (Gossypium hirsutum L.). Environ Exp Biol 87-94.

16. Shahzad AN, Rizwan M, Asghar MG, Qureshi MK, Bukhari SAH, Kiran A \& Wakeel A (2019). Early maturing Bt cotton requires more potassium fertilizer under water deficiency to augment seed-cotton yield but not lint quality. Sci Rep 9: 7378 .

17. Ryan J, Estefan G \& Rashid A (2001). Soil and plant analysis lab manual. 2nd ed. International Center for Agricultural Research in the Dryland Areas (ICARDA), Aleppo, Syria. pp. 172.

18. Zia-ul-hassan, Arshad M \& Khalid A (2011). Evaluating potassium-use-efficient cotton genotypes using different ranking methods. J Plant Nutr 34: 1957-1972.

19. Aladakatti YR, Hallikeri SS, Nandagavi RA, Naveen NE, Hugar AY \& Blaise D (2011). Yield and fiber qualities of hybrid cotton as influenced by soil and foliar application of potassium. Karnataka $J$ Agric Sci, 24(2): 133-136.

20. Tsonev T, Velikova V, Aktas LY, Gürel A \& Edreva A (2011). Effect of water deficit and potassium fertilization on photosynthetic activity in cotton plants. Plant Biosyst 1: 1-7.
21. Cope JT (1981). Effects of 50 years of fertilization with phosphorus and potassium on soil test levels and yields at six locations. Soil Sci 45: 342-347.

22. Brouder SM \& Cassman KG (1990). Root development of two cotton cultivars in relation to potassium uptake and plant growth in a vermiculitic soil. Field Crops Res 23:187-203.

23. Rosolem CA \& Mikkelsen DS (1991). Potassium absorption and partitioning in cotton as affected by periods of potassium deficiency. J Plant Nutr 14(9): 1001-1016.

24. Zia-ul-hassan \& Arshad M (2010). Cotton growth under potassium deficiency stress is influenced by photosynthetic apparatus and root system. Pak J Bot 42(2): 917 - 925.

25. Makhdum MI, Pervez H \& Ashraf M (2007). Dry matter accumulation and partitioning in cotton as influenced by potassium fertilization. Biol Fert Soils 43(3): 295-301.

26. Pervez $\mathrm{H}$, Ashraf $M$ \& Makhdum MI (2004). Influence of potassium nutrition on gas exchange characteristics and water relations in cotton. Photosynthetica 42(2): 251- 255.

27. Reddy KR, Koti S, Davidonis GH \& Reddy VR (2004). Interactive effects of carbon dioxide and nitrogen nutrition on cotton growth, development, yield and fiber quality. Agron J 96: 1148-1157.

28. Akhtar ME, Sardar A, Ashraf M, Akhtar M \& Khan MZ (2003). Effect of potash application on seed cotton yield and yield components of selected cotton varieties - I. Asian J Plant Sci 2(8): 602-604.

29. Pettigrew WT (2008). Potassium influences on yield and quality production for maize, wheat, soybean and cotton. Physiol Plantarum 133: 670-681.

30. Sweeney DW, Granade GV, Eversmeyer MJ \& Whitney DA (2000). Phosphorus, potassium, chloride, and fungicide effects on wheat yield and leaf rust severity. $J$ Plant Nutr 23: 1267-1281. 